\title{
Reflections on China's rural financial service innovation
}

\author{
Liu Jianbo \\ School of Economics and Management, Weifang University \\ ljbwfu@126.com
}

Keywords: rural finance; credit structure; financial organizations

\begin{abstract}
In current, China's rural financial system is not perfect, the issues of imbalance rural credit structure and others are outstanding, resulting in a low level of rural financial services. In the third plenary session of the eighteenth communist party of China, it has put forward new demands for China's rural financial service innovation, which urgently needs us to explore the innovative strategies of rural financial services, such as in the aspects of property relations of financial organizations in rural, promoting microcredit business in rural financial services, accelerating rural credit products and services to adapt to the new economic and social development in rural areas.
\end{abstract}

\section{The status analysis of China's rural financial services}

At present, China's rural financial services have many problems in terms of multi-level financial products demand, financial services mode, and financial competition mechanism, etc. the rural financial system is still in an unsound development stage, lack of richness [1]. Meanwhile, rural financial services is also in a facility lacking state. New rural construction, urbanization and the development of modern agriculture requires a lot of financial support, which put forward higher requirements for China's rural financial service innovation. In other words, rural financial services is the material basis for agricultural development, it plays an important role in promoting new rural construction, urbanization and the development of modern agriculture.

Due to the constraints of the financial system, in current, the main force of service for "three rural" is rural credit cooperative organizations. from 2012 to 2013, the statistical data of China's rural credit cooperatives (quarter is the unit), mainly included the reserve assets (the number of the end of a month) in the rural credit cooperatives, reserve fund (the number of the end of a month), cash on hand (the number of the end of a month), the central Bank bonds (the number of the end of a month), the government debt (the number of the end of a month), etc. It can be found in the four quarters of 2012, the data of rural credit cooperatives' reserve assets are imbalance. While in 2013, the data of rural credit cooperatives' reserve assets are stabilized, but relative to 2012, it is showing a growth trend, which to some extent indicates the condition of rural financial market; in 2012 to 2013, reserve assets of rural credit cooperatives - reserves funds (the number of the end of a month) are stabilized; the change of reserve assets of rural credit cooperatives - cash on hand (the number of the end of a month) is relatively large, from 2012 to 2013, in several quarters it is declined, and in a unstable state of development; the data of assets of rural credit cooperatives - the central bank bonds (the number of the end of a month) in the beginning of the first quarter of 2012 and the quarter of the end of 2013 are closed, while in the middle, the development is also tend to the balance state; The data of rural credit cooperatives on government debt (the number of the end of a month) appeared reducing state in the unstable trend, especially in the last two quarters of 2013. Thus, rural credit cooperatives have a significant impact on China's rural financial services market, each set of data of rural credit cooperatives will indirectly affect China's rural financial development.

Table1:The data of rural credit cooperatives from 2012to2013 


\begin{tabular}{|c|c|c|c|c|c|}
\hline index & $\begin{array}{l}\text { reserve assets } \\
\text { of rural credit } \\
\text { cooperative } \\
\text { ( the number } \\
\text { of the end of a } \\
\text { month) }\end{array}$ & $\begin{array}{l}\text { reserve assets } \\
\text { of rural credit } \\
\text { cooperative- } \\
\text { reserve fund } \\
\text { (the number } \\
\text { of the end of a } \\
\text { month) }\end{array}$ & $\begin{array}{l}\text { reserve assets } \\
\text { of rural credit } \\
\text { cooperative- } \\
\text { cash on hand } \\
\text { ( the number } \\
\text { of the end of a } \\
\text { month) }\end{array}$ & $\begin{array}{l}\text { assets of rural } \\
\text { credit } \\
\text { cooperative- } \\
\text { the central } \\
\text { bank bond } \\
\text { (the number } \\
\text { of the end of a } \\
\text { month) }\end{array}$ & $\begin{array}{l}\text { rural credit } \\
\text { cooperative- } \\
\text { government } \\
\text { debt (the } \\
\text { number of } \\
\text { the end of a } \\
\text { month) }\end{array}$ \\
\hline Area & National wide & National wide & National wide & National wide & $\begin{array}{l}\text { National } \\
\text { wide }\end{array}$ \\
\hline $\begin{array}{l}\text { frequentne } \\
\text { ss }\end{array}$ & Month & Month & Month & Month & Month \\
\hline Unit & billion & billion & billion & billion & billion \\
\hline 2012-03 & 1069.53 & 797.97 & 89.76 & 63.47 & 13.74 \\
\hline 2012-06 & 1054.9 & 960.91 & 93.99 & 57.38 & 9.45 \\
\hline 2012-09 & 1070.94 & 972.34 & 98.3 & 57.7 & 10.01 \\
\hline 2012-12 & 1324.51 & 1239.17 & 85.34 & 53.73 & 5.83 \\
\hline 2013-03 & 1190.6 & 1094.4 & 96.1 & 51.9 & 13.6 \\
\hline 2013-06 & 1160.4 & 1064.6 & 95.8 & 50.6 & 11.4 \\
\hline 2013-09 & 1180.3 & 1079 & 101.2 & 51.8 & 8 \\
\hline 2013-12 & 1385.5 & 1299.7 & 85.8 & 63.2 & 8.8 \\
\hline
\end{tabular}

Meanwhile, the following data is also a good indication of the status of rural finance. For example, seem from more than ten years development situation from 2000 to 2013, the balance of urban and rural residents' savings deposits at the end of the year are increased gradually, which are closely linked with the living standard of urban residents, it is the most powerful performance of the rapid development of rural productivity. While, although the annual increased amount of urban and rural residents' savings deposits showed an unstable situation, seem from recent developments this year, the increased range of urban and rural residents' savings deposits is very large, from less than ten thousand at the beginning increasing to the amount of more than twenty thousand, the increased magnitude is evident. From the above data of balance of urban and rural residents' savings deposits at the end of the year and the annual increased amount of urban and rural residents' savings deposits, it can be found that with the improvement of living standards of urban and rural areas, the rural urban income is gradually increasing, the standard of living is getting better, we can say, these data suggest that the prospects for the development of China's rural financial market is optimistic, especially after 2000, in the last ten years of the development process, the pace of development of China's rural financial market is also advancing with the times.

Table2:Balance and increase the amount of The savings deposits of urban and rural residents

The balance of urban and rural

index residents's saving deposits at the end of the year

\begin{tabular}{ccc}
\hline area & National wide & National wide \\
frequentne & Month & Month \\
ss & billion & billion \\
unit & 5340.747 & 712.767 \\
2000 & & \\
\hline
\end{tabular}

Annual increase of rural residents' saving deposits 


\begin{tabular}{lcc}
\hline 2001 & 5962.183 & 621.436 \\
2002 & 6433.238 & 471.055 \\
2003 & 7376.343 & 943.005 \\
2004 & 8691.065 & 1314.822 \\
2005 & 10361.765 & 1670.7 \\
2006 & 11955.539 & 1593.774 \\
2007 & 14105.099 & 2149.56 \\
2008 & 16158.73 & 2054.4 \\
2009 & 17253.419 & 1094.69 \\
2010 & 21788.535 & 4535.116 \\
2011 & 26077.166 & 4288.631 \\
2012 & 399955.1 & 5591.5 \\
2013 & 44760.16 & 4805.056 \\
\hline
\end{tabular}

\section{The facing issue of China's rural financial service innovation}

(1) the rural financial system is not perfect

Under China's current rural financial system, the amount of the financial institutions' distributions are unreasonable, resulting in the imbalance set of financial institutions. In today's rural areas, due to the state-owned commercial banks are gradually withdrawn from the bank in the county, resulting in that the financial institutions in rural areas lost some function, the most obvious is the lack of lending functions. Meanwhile, some Agricultural Development Bank seemingly able to play a significant role are also began to lose power, there are many problems itself, it can be said, because the property of Agricultural Development Bank is not enough clarity and the service means are not all advanced, the role of credit support for agriculture has gradually weakening. In addition, like the credit cooperative bank which is serviced rural construction, although the scope of loans can cover more than half of the rural areas, the designation of their clients is stronger, and ultimately it cannot be able to fully provide comprehensive services to rural finance. The unsound reason of rural financial system is multifaceted, it is closely linked with the current financial system and ideology, it can be said, the construction of China's rural financial system is not easy, and it needs mutual cooperation between the government and financial institutions and efforts to solve effectively.

(2) Rural credit structure is not balanced

In today's rural financial service system, the imbalance between the rural spending funds and demanding funds greatly restricted the efforts of rural finance, which will lead to imbalance rural credit structure occurs. In the process of the new rural construction, many constructive agricultural production will be impacted by some financial institutions' system sometimes and it will occurs the uneven phenomenon between credit and economic development. Although the development of China's rural finance has made some great progress, it is undeniable that for some rural agricultural production, the delay of financial credit is not fully consistent with the laws of the agricultural production cycle, to some extent, which greatly affected the farmers' income [3]. The Status of China's rural agriculture has evolved from extensive transition to the mode of growth and efficiency, the rural agricultural has been considerable development. Forestry and fisheries present an innovative processing stage, we can say, agriculture demanding for funds can be described as an increasingly improved. however, in today's China's rural credit system, because the rural credit structure is not fully track the development of the agricultural economy, a number of innovative 
financial services are not able to fully adapt to the development, the credit adjustment exists difficulties, China's rural financial service system for innovative reforms is significant.

(3) The level of rural financial services is not high

In the process of development in recent years, China's rural culture had been gradually building up, and with the development of rural society, the level of rural financial services has yet to be improved. In rural financial services, there is also the phenomenon of low level of service, financial services are single, settlement and management system is relatively backward, while the varieties of credit are relatively simple, it cannot meet the rapid development of the rural economy [4]. In rural financial institutions, rural credit cooperatives is one of the typical organization. But seem from its financial services, the rural credit cooperatives in the financial services have some drawbacks, which mainly includes single financial credit services, imbalance business services, and lack of awareness of credit service innovation and other issues [5]. For the level of rural financial services is not high, we should find ways to resolve from the mechanism. With the accelerated pace of new countryside, the level of rural financial services in an area directly determines the quality of the rural economic development. Today, in the industrialization of agriculture, rural financial services is its major boosters, if it has a certain lack of financial services support, rural economic development is bound to be affected.

\section{The innovation strategy of the rural financial service}

(1) Property relations innovation of rural financial organizations

The innovation of property rights of the rural financial is one of the strategies to promote rural financial services innovation. The property rights of financial organization system is the core innovation of rural financial services, property competing with high efficiency can promote diversified development of the rural economy. in the financial services innovation model, the system of property rights need to innovate, to abandon the traditional business model of excessive government guidance, and to make gradual transition to a demand-induced type direction, as well as to play the greatest degree of self-innovation ability of financial organizations. Governments throughout the process is more played the role of supervision and guidance, so as to promote rural financial services innovation. In the innovation of property relations of rural financial organizations, it must first define what the center of property relations is. Co-production is made as the ultimate form of property relations of financial institutions, which is the basis of innovation and reform. Meanwhile, the important financial institutions are made reposition of property relations, forming a multi-level service mechanisms, For example, rural credit cooperatives are made the property rights system innovation, the county's credit cooperatives are made as the first legal person, at the same time, based on the same level, many financial institutions are combined to form a multi-level property right mechanism under a provincial legal regime.

(2) The innovation of microcredit business in rural financial services

Relative to the number of commercial banking institutions, China's rural financial institutions in the credit business has some obvious disadvantages, a very important reason is that there is no good functioning of rural financial services in microcredit business. In rural financial services, microcredit credit business has an important role in the rural financial service system, which to some extent affected the rural financial service system. The amount involved in rural credit operations is relatively smaller, so in the agricultural credit aspect, the borrower cannot meet the eligibility conditions for corporate borrowers. In today's rural financial services, in microcredit business, a healthy operating mechanism is particularly important, the government should carry out macro arrangements and plans to organize and supervise the work, and financial institutions should be a line credit services, and adopt a combination form of centralized and decentralized, while the government and financial institutions should make stringent checks in payment of the credit process to ensure the safety of lending funds.

(3) Rural credit products and service mode Innovation

Rural credit products and services approach are the unified. Innovative rural credit products directly affects the innovative services mode. In view of the current status quo of China's financial 
services, it needs to conduct innovative financial services system, and the optimization and upgrading of credit products is indispensable. Today, China's rural financial service needs joint effort together. On the one hand, during the innovation of rural credit products, financial institutions can release some financial products with innovative features, but also opened up the business scope of financial institutions, through innovative financial products to attract the attention of customers. In addition, a class of security guarantees products can also be introduced into the credit products, including the mortgage of property, trademark right and assets and so on. On the other hand, in the service mode, it can combine innovative varieties, expand the scope of services. Therefore, in the innovation of rural financial products and services, the financial institutions in various regions should develop strategies according to adjust measures to local conditions, thereby to form the creative brand.

\section{References}

[1] Wen Tao. realistic thinking on promoting the rural financial service innovation under new situation- based on rural comprehensive reform pilot area in Chongqing Province [J] Agricultural economy problem, 2010 (10).

[2] Man Mingjun, Zhou Minliang. Reflections on China's rural financial service innovation model [J]. Innovation, 2013 (03).

[3] Li Xiuru. China's innovative financial products and inquiry of services innovation in rural areas under functional perspective [J]. Journal of Yanbian University, 2013 (04).

[4] Tian Xuesi, Gao Lianshui. Thinking on the reform of development of China's rural financial [J]. Gansu Social Sciences, 2013 (05).

[5] Zhang Zhaohai. Analysis of the factors to restrict rural financial service innovation and policy recommendations. [J]. Wuhan Finance, 2011 (02). 